\title{
The Notau harbour and the Kontor in Bergen
}

\author{
GEIR ATLE ERSLAND
}

Ersland, G. A. 2019. The Notau harbour and the Kontor in Bergen. AmS-Skrifter 27, 237-244, Stavanger, ISSN 0800-0816, ISBN 978-82-7760-183-0.

The Hanseatic Kontor in Bergen was one of the main hubs of trade in the North Sea region. This paper explores a possibility suggested in a late sixteenth-century manuscript that the Norwegian Kontor for some time was also located at Notau, a place south of Bergen. It is argued that this written source might refer to the years 1427-33 when the Hanseatic merchants withdrew from Bergen because of an on-going war between King Erik and northern German princes. Notau is mentioned several times in sources from the fifteenth century and most of these references are related to Hanseatic activity. However, viewed in a broader context, Notau stands out as an important harbour on the south-western Norwegian coast, visited both by Norwegians and Hanseatics, as well as travellers from other regions.

Geir Atle Ersland, Department of Archaeology, History, Cultural Studies and Religion, Bergen University, P.O.box 7805, N-5020 BERGEN, NORWAY. E-mail: geir.atle.ersland@uib.no

Keywords: Hanseatic Kontor, Bergen, Eric of Pomerania, pirates, Die Nortsche Saw, war

We are told in a late sixteenth-century manuscript called 'Die Nortsche Saw' (The Norwegian Sow) that the Hanseatic towns founded four Kontors: in Bruges in Flanders, London in England, Novgorod in Russia and the fourth in Norway. According to the manuscript, this last one for some time was located at Notau, but only briefly as piracy made it necessary to find a safer location in Bergen. ${ }^{1}$ The overall picture given here complies well with our understanding of the Hanseatic Kontors, except for the information about the Norwegian Kontor located at Notau. On the one hand this has been given little regard by historians, since it is the only written source mentioning such a location. On the other hand recent archaeological research has stimulated current research to the whereabouts of Notau. Notau as a place of interest in the late medieval trade from western Norway is confirmed by several written sources and the location is found on older maps of the coastline. ${ }^{2}$ It is mentioned five times in Bruns' edition of sources related to the Kontor in Bergen and the Bergenfahrer society in Lübeck. ${ }^{3}$ The main purpose of this article is to attempt to make sense of the claim from the late sixteenth-century author that the Kontor in Norway for some time was located at Notau, and to what extent it was a harbour dominated by Hanseatic activity.

\section{'Die Nortsche Saw' manuscript}

'Die Nortsche Saw' is an example of early modern polemical literature with a strong emphasis on historical argumentation (Fig. 1). We do not know anything about the author. However, based on the fact that the text is written in German, we can assume that he was not Norwegian. ${ }^{4}$ It has been a common assumption among those who have worked with the text that the author was of northern German origin. Nine handwritten copies of the manuscript have survived. ${ }^{5}$ The original is believed to have been lost, and the copies seem to have been made during the seventeenth century.

The survival of different copies originating over a period of at least one hundred years indicates some kind of popularity or significance of the text. Based on this we must assume that the surviving copies are just a few of many which were in circulation at one time or another, but which have been lost in the course of time. 'Die Nortsche Saw' was not printed until the Norwegian antiquarian, Nicolay Nicolaysen published 


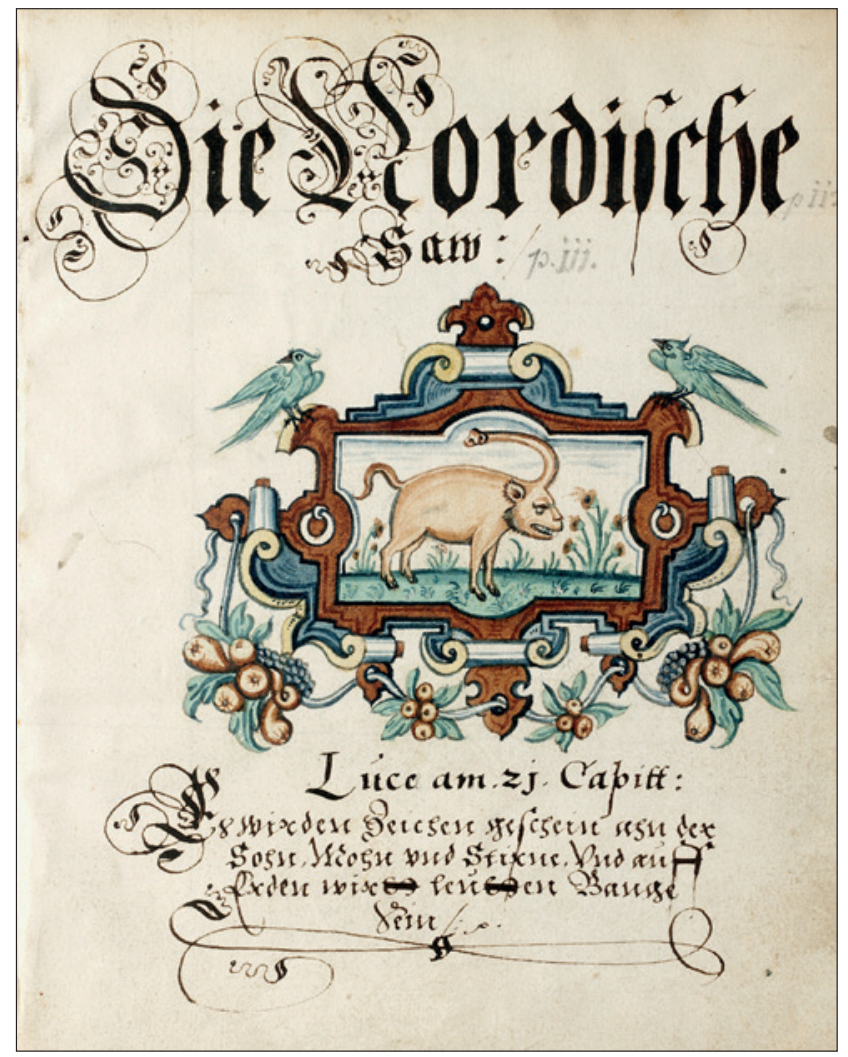

Fig. 1. Front page of 'The Nortsche Saw' manuscript. The illustration is explained as follows: 'Ich bin unt heis die Nordtsche Saw, Hab ein Haut, wie ein schöne Fraw. Mit mir bolieren edel und unedel Leut, Darzu aller Nationen Kauffleut. Ich fres, scheis, spey, leg mich nieder, Steh auf, und begin es wieder. Ich hab Ohren wie Affen-Ohren, Thu offt vom Jüngsten Tage hören, Wie Gott das böse wirdt straffen, Ich achte es soviel als die Affen. Bin also sehenden Augen blint, Hab eine Nase alse andere Menschen Kint, Denne will ich kein Gestanck schmecken, Bis ich Gottes Zorn thu erwecken. So ist doch Sweine-Fleisch mein Leib, Ein Saw noch wie zuvor ich bleib.' (image Kgl. Bib. GKS 2838, text from NM 2, 3f.).

a version in 1868 which he gave the Norwegian title 'Den norske So'. He set aside the fact that the language was German, and decided to publish it in 'modersmålet', his mother tongue. He reckoned that the original language had no value since it was an inconsistent mix of High and Low German. ${ }^{6}$ However, this was a radical premise which has influenced most historians that have used Nicolaysen's version, and to my knowledge this goes for all who have used 'Die Nortsche Saw' as a source. It is quite frequent to find that the 'mother tongue' version is cited as if this is the original and not a translated text.

Nicolaysen published only parts of the manuscript, and based this on the argument that the allegories, the supposed signs given by God and the moral indignations, had no historical value. He therefore chose to publish those parts which he believed was of interest to the historian. ${ }^{7}$ For all those who want to use 'Die Nortsche Saw' it is of course of crucial importance to be aware of how Nicolaysen decided to edit his version. The linguist Agnete Nesse has pointed out that the language used is an early example of High German used in Bergen, and that Nicolaysen's publication is not a reliable text for research purposes. ${ }^{8}$ Even more crucial is the fact that the printed version is shortened in such a way that it is hard for any reader to get a thorough impression of the character of the manuscript and its content.

By studying the surviving copies, we find that the content can mainly be divided into three sections. The first section is an allegory in which Norway is portrayed as a basket for carrying hens and chickens. These were of all kinds and colours and the larger bullied the smaller, and as the environment in Norway for making a living was harsh, it was made even worse thanks to the other varieties of birds living outside the basket. The second part is concerned with the temporary moral issues, of which the author is highly critical. In this part certain persons are mentioned, but their identity is concealed by writing their names in a coded script. The third part is concerned with all the signs to be seen in the sky that should make people anxious, because they are meant to be God's warning to the people on earth to change their ways or else face the grim consequences of their immoral actions. ${ }^{9}$

\section{An early modern perspective on the Hanse in Norway}

We find elements through all three parts of 'Die Nortsche Saw' that indicate that the core of the manuscript is history writing and the main theme is the history of Bergen and especially the town's relations to the Hanseatic merchants residing there. A crucial question for the evaluation of the text is how well informed was the author of the circumstances which resulted in an organized Hanseatic settlement in Bergen? Even though the author mentions why and where the four Hanseatic Kontors were founded, he does not say when. He writes that the first Kontor was established in Bruges in Flanders, where they traded in gold, silver, precious stones, velvet and silk. These goods were brought from Spain and France. The second Kontor was placed in London in England, where most of their trade consisted of cloth. The third Kontor 
was situated in Novgorod in Russia, where they got hold of furs, wax and tallow. The fourth Kontor they founded in Norway. ${ }^{10}$ He then commences to tell the story of the decline of the power of the Hanse, noting that the English Kontor was dissolved in 1578, and that from now on only the Norwegian Kontor remained. After this the author gives a more detailed description of the early development in Bergen and tells his reader that the Kontor was founded with the intention of importing flour, malt, beer and cloth. There was an abundance of fish, and servants of merchants came sailing from all the Hanseatic towns. We are told that this was a golden age, but matters did not develop peacefully and to the mutual benefit of both Germans and Norwegians. The Hanseatic merchants terrorized the inhabitants of Norway, and for this reason they were not allowed to stay in Bergen during the winter season. ${ }^{11}$

It seems that the author of 'Die Nortsche Saw' was of the opinion that an organized society of German merchants was first established in Bergen prior to the reign of King Erik (1389-1442), but during his reign there was a conflict between the king and the Hanseatic towns. We are told that the merchants from the Hanseatic towns burnt down Bergen, and trade was suspended. Trade was revived when King Christopher (1442-48) made a new agreement with the Hanseatic towns. The poor Norwegians were now treated fairly and the Hanseatic merchants were allowed to stay in Bergen over the winter. The trade started once again to flourish and everything was organized in a better fashion. The author of 'Die Nortsche Saw' recommends that anyone seeking more knowledge on these questions should read the book about the founding of Bergen as a guide to these matters. ${ }^{12}$ There can be little doubt that the book in question is the 'Bergen Fundas' (The Founding of Bergen), which was written probably in $1559 .{ }^{13}$ As with 'Die Nortsche Saw', 'Bergen Fundas' was also circulated in the form of handwritten copies and first printed in $1858 .{ }^{14}$

The author of 'Bergen Fundas' was well aware of the fact that German merchants acted as a privileged group from the second half of the thirteenth century and informs his readers how Bergen was plundered and burned by the Germans from Wismar during the conflict between King Albrecht of Mecklenburg and Queen Margaret in the 1390s, and also that the same happened during the conflict between the Hanseatic towns and King Erik. However the Hanseatic towns were not able to get the upper hand, and a peace agreement was negotiated. ${ }^{15}$
The accounts given of the events during the conflict with King Erik, the peace agreement and the return of the German merchants in both 'Die Nortsche Saw' and 'Bergen Fundas', are far from flawless, not least because the narratives are strongly biased in favour of the Norwegians. The core of the conflict, the rivalry between King Erik and the counts of Holstein over the control of the duchy of Schleswig, is hardly commented on, nor that the Germans abandoned Bergen in the spring of 1427 and returned by the end of July $1433{ }^{16}$ This was actually two years prior to the peace agreement, which was settled in 1435 , and was probably a direct result of the agreement of a five-year truce between the parties in $1432 .{ }^{17}$ Contrary to 'Bergen Fundas', 'Die Nortsche Saw' states that the peace agreement was made with King Christopher (1442-48). However, in 1435 King Erik was still ruler of the three Scandinavian kingdoms. The Swedish and Danish aristocracy renounced their allegiance to King Erik in 1439 and the Norwegians in 1442. Christopher on the other hand was elected King of Denmark in 1440, Sweden in 1441 and Norway in 1442. Why the author of 'Die Nortsche Saw' states that trade was revived by an agreement with King Christopher, is puzzling. There is the possibility that the author has confused the peace agreement in 1435 with the negotiations on the renewal of the Hanseatic privileges in Bergen, culminating with King Christopher's letter on the rights and duties of the Hanseatic merchants issued in December 1444. ${ }^{18}$

\section{A hypothesis of the 'Kontor at Notau'}

According to modern historiography there can be no doubt that the Hanseatic merchants had established themselves in the Bergen trade as early as the thirteenth century and that an organized group of merchants with extra-territorial rights was established there in the 1360s. As the starting point for the Kontor the events in the 1360s, when a society of Hanseatic merchants in Bergen governed by aldermen is mentioned for the first time, are emphasized. ${ }^{19}$ However, it has been argued that the Kontor was in the process of formation as early as the 1343 when the Germans in Bergen were given the right to form their own society. ${ }^{20}$ With regard to modern research, it is most tempting to discard the information in 'Die Nortsche Saw' of the Norwegian Kontor for some time located at Notau as false, or at best as misleading due to the lack of deeper knowledge by the author. However, as demonstrated, both the events and use of terminology can be confusing. 
The Norwegian historian, Yngvar Nielsen wrote in his history of Bergen published in 1877, that a new Kontor was established shortly after 1435 , since the former had been dissolved when the Germans left Bergen in 1427. ${ }^{21}$ This idea of a new Kontor seems to be confirmed by the fact that in the $1440 \mathrm{~s}$ at the latest, several administrative innovations were introduced. A building called 'Copmansstaven', later called 'Das Kaufmannshaus', was constructed. The internal court, consisting of the 'Aldermen', was strengthened with a larger group, the 'Achteinen', and a secretary in charge of the Kontor's affairs was employed. These undertakings, made in order to strengthen the colony of foreign merchants' interests, are some of the measures mentioned by the author of 'Die Nortsche Saw'. ${ }^{22}$ In addition, we are also presented with a detail that might be of some significance. It is explicitly stated in 'Bergen Fundas' that it was after King Christopher's letter (1444) that the Germans started to call their quarters a Kontor. It is also said that it was from then on that the Germans adopted the practice of becoming permanent residents in Bergen by staying through the winter. ${ }^{23}$

As we can see from the 'Bergen Fundas' there is a question of terminology to be considered when it comes to calling the German body in Bergen a Kontor. The term, Kontor, actually occurs for the first time in a manuscript from 1494 containing the internal regulations for the Hanseatic settlement in Bergen. However, these regulations are for the most part copied from a text which mainly dates prior to 1464 . We learn from other sources that in the fourteenth century the official name was 'Olderlude unde Copmans to Berghen', or variations in Latin or Low German like 'Communis mercator hanse Theutonice Bergis existens', 'communis mercator de Berghen' or 'de (ge)mene kopman to Berghen'. 'Nedderlage' is known as early as the 1420s, and is common from 1440s. One should also note that the older terminology was still in use parallel to new names, and that in modern history writing Kontor is used indiscriminately. At this point it is worth mentioning that it is not stated in 'Die Nortsche Saw' that the Kontor was first placed at Notau and thereafter moved to Bergen. What it does say is that a Kontor was founded in Norway like in Bruges, London and Novgorod, and for some time the Norwegian Kontor was located at Notau. ${ }^{24}$

There seem to be good reasons to argue that after the return to Bergen, measures were taken to reorganize and improve the settlement of German merchants in Bergen. The author of the 'Bergen Fundas', as already pointed out, emphasizes that it was during the reign of
King Christopher that they started to call it a Kontor. And from that moment on, the abundance of archival records gives no room for suggesting that the Kontor at any time later was situated anywhere else than in Bergen. ${ }^{25}$ The Kontor's permanent existence in Bergen from the 1430s until the 1760s cannot be doubted. If the information about the Kontor at any time being located at Notau should have any bearing, the latest period in question is the years during the conflict with King Erik in the second half of the 1420s.

It was merchants from the Wendish towns of Lübeck, Wismar, Stralsund and Lüneburg who had left Bergen in spring 1427 and who returned in $1433 .{ }^{26}$ They had been reluctant to leave in the first place, and in January 1427 the 'Aldermen' had informed the town council in Lübeck that they had made a local peace agreement with the King's representative at the castle in Bergen. ${ }^{27}$ The residing merchants were probably worried that if they left this would give English merchants an opportunity for a firmer grip on the trade, but also that Hanseatic merchants from other towns probably would be in an even better position to take over the established trade. ${ }^{28}$

It is at this point useful to underline the explanation the author of 'Die Nortsche Saw' puts forward as to why the Kontor stayed at Notau only for a short time: it had to be moved to Bergen which was a safer place because of piracy. Indirect evidence that might support that this happened during the conflict with King Erik can be retrieved from the details coming to light during the peace negotiations which took place between the Hanseatic towns and the King in 1434. Here it is mentioned twice that two German merchant ships from Danzig were deprived of goods in 1430. One was shipwrecked at Notau, and the Norwegian bailiff confiscated the salvaged goods. The other ship was plundered at Notau by pirates from Denmark and Norway who supported King Erik. ${ }^{29}$ The two incidents in fact indicate that both the King's bailiff and DanishNorwegian pirates were active at Notau and that this was no safe haven for Hanseatic ships.

The troubles at Notau took place at least three years before the merchants' return to Bergen in 1433. Could it be these incidents which are referred to in 'Die Nortsche Saw' when it is said that the Kontor was moved from Notau to Bergen because of piracy? In the summer of 1432 there was an encounter in Bergen. The Victual Brothers (Vitalienbrüder) threatening to use force had taken supplies from ships from Danzig. ${ }^{30}$ At the same time seventeen English ships also visited Bergen, and the English accused the skippers from 
Danzig of being in allegiance with the pirates, and had made them compensate for the English losses caused by the pirates. ${ }^{31}$ These instances are mentioned during the negotiations between the Danish-Norwegian government and the towns of Stettin and Danzig regarding compensation for damages and losses caused by Danes and Norwegians to Hanseatic merchants who were not part of the conflict. ${ }^{32}$ Since we find that ships from Danzig were present at Notau in 1430, despite the withdrawal from Bergen by the Wendish towns, western Norway was not totally cut off from contact with Hanseatic merchants.

Could it be that German merchants not belonging to the Wendish towns, after the retreat from Bergen in 1427 , tried to carry on with their trade from Notau, and in that way sought to avoid relinquishing trade in Norway? And could it be that the merchant ships from Danzig preferred sailing to Bergen after they had experienced both piracy and having the king's bailiff taking goods from them at Notau in 1430? We have to admit that no written source seems to give any conclusive evidence. However, if there is any bearing in the information of the earliest Kontor, as related by the author of 'Die Nortsche Saw', the context is within the conflict between King Erik and the Wendish towns and the re-establishment of the Hanseatic settlement following the peace agreement in 1435. As an answer to the question of whether there is any relevance to discuss the remark about a Kontor at Notau, it therefore appears to be plausible to confine this to the period between 1427 and 1433.

\section{Evaluating the Hanseatic presence at Notau}

The archaeological artefacts found at the seabed at the site of what is believed to be the harbour of Notau, roughly date to the period between 1300 and 1550, with a peak in the fifteenth century. ${ }^{33}$ The archaeological findings seem to indicate that Notau must have been in existence for some time and well known to merchants sailing between Bergen and Lübeck. This fits in well with the written sources where Notau is mentioned. The oldest one is dated 1425, and is found in the will of Johan van Berne in which he gave two barrels of tar for building activity at Notau. Similar donations are given to churches in Bergen, and most likely the donation mentioning Notau was meant for a church close by, presumably the church at Avaldsnes. However, the term 'to deme buwe' might also indicate that the tar was meant for some kind of on-going building purpose. ${ }^{34}$ If so, this might indicate that there existed, or maybe was planned, some kind of religious institution in Notau at the time when the will was made. The possibility that the building activity might refer to a non-religious purpose has to be consider against the fact that every other donations found in the 231 preserved late medieval wills by Bergenfahrers are either to persons or religious institutions. ${ }^{35}$ In light of this any secular application for the two barrels can hardly be regarded a likely possibility. It is also important to keep in mind that wills give plenty of information about locations in Norway, which we might assume are mentioned because the donator was personally attached to the places and not because they were particular Hanseatic places of interests.

One of the most remarkable references to Notau occurred in 1453 when the Norwegian archbishop, the Danish-Norwegian king and members of the Danish and the Norwegian Sovereign Council anchored their ships at Notau in October that year after a meeting in Bergen where the archbishop had agreed to resign and temporarily take up residence in Stavanger. However, at Notau the King changed his mind, and now ordered the dethroned archbishop to settle in Marstrand, close to the Danish border. This high-profile meeting gives no indications of any Hanseatic presence at Notau. ${ }^{36}$ We might assume that this was a natural stop-over for the archbishop en route from Bergen to Stavanger. And probably this was also the case for anyone traveling along the western coast of Norway, which also explains why two English ships turned up at Notau in 1454. We owe our knowledge of this to the fact that they were attacked by Hanseatic ships as a retaliation for an English assault on Hanseatic ships on the coast of Denmark. ${ }^{37}$ However, the point to be underlined is that it is quite obvious that the English ships arrived in Notau of their own free will, and it is hard to believe that they would seek it out if it were known to be a place under Hanseatic control.

Representatives from Kampen and Deventer made complaints to the Hansetag in Lübeck and Bremen in 1476 with regards to merchants from the two towns being charged with payments by members of the Kontor in Bergen, for assistance given upon arrival at Notau. ${ }^{38}$ However, this is not conclusive as evidence for permanent Hanseatic residence or presence at Notau; it only suggests the temporarily presence of merchants from the Kontor in Bergen. That the Hanseatic presence at Notau had a seasonal character seems to be confirmed by the Lübecker Bergenfahrers Schüttingsrechnungsbuch, where it is mentioned that in 1471 there had been merchants staying through the 
winter at Notau. ${ }^{39}$ The entry in the book seems to indicate that this was not common, and indirectly it might be read as evidence for the normal practice being that Hanseatic presence at Notau might have been related to the sailing season in the summer half of the year.

There is actually little in the written sources which indicates that Notau was a harbour or settlement dominated by the German merchants or politically controlled by the Hanse. While most of these sources relate to matters where Hanseatic interests are involved, this must be regarded as a consequence of the fact that Hanseatic records are preserved. The meeting at Notau between the King and the archbishop in 1453 makes it more likely that this was a harbour used by ships en route from Bergen to Denmark or the continent. This also explains why English merchant ships turned up at Notau. The location of Notau close to Avaldsnes placed it firmly on the main sailing route along the coast of western Norway. The narrow strait between the island of Karmøy and the mainland situated Avaldsnes in an ideal position for controlling the seafaring traffic, and supports the interpretation that this was one of the strategic focal points in the early process of conquest and unification of the kingdom of Norway. ${ }^{40}$

The proximity to Stavanger must also be taken into consideration when evaluating the role of Notau as a harbour. Apart from Bergen, Stavanger was the only town along the western coast of Norway in the fifteenth century. Stavanger's importance as an urban community was based on its role as a bishop's see, with a population probably never reaching more than 600-800 before 1350 and decreasing after that. ${ }^{41}$ Stavanger did not in any way represent a trading port of importance compared to Bergen. However, in 1425 King Erik issued a letter which revitalized former regulations which forbade anyone to trade within the bishop's see of Stavanger, except in Stavanger itself or in other locations were trade had been legal earlier. ${ }^{42}$ The question to be asked, with the 1425 letter in mind, is whether Notau was such a place where trade was legal according to older regulations, or if the intention was to curb such activity here and elsewhere within the province of the bishop of Stavanger? In the truce made between King Erik and the counts of Holstein and Hamburg, Lübeck, Wismar and Lüneburg, it is stated that within Norway the Hanseatic merchants should be allowed to trade in Bergen and Stavanger according to their old privileges. ${ }^{43}$ This is the only time Stavanger is mentioned as a place where the Hanseatic merchants could trade according to their privileges, and it might indicate that traditional trading in the vicinity of Stavanger was common and accepted by Norwegian authorities.

\section{Conclusion}

If my reasoning in the above has any bearing, the remark about Notau in the late sixteenth-century manuscript 'Die Nortsche Saw' about the Kontor refers to the situation during the conflict with the Hanseatic towns and King Erik in the 1420s and early 1430s. Since 'Die Nortsche Saw' is the only written source that mentions that the Kontor at one time was situated at Notau, it is of course tempting to reject the remark as the writing of a misinformed author. The backdrop for this might have been a strong presence of Hanseatic ships and merchants at Notau in the fifteenth century, which had been turned into a local tale by the sixteenth century about how the famous Kontor in Bergen had its roots at Notau. However, when trying to piece together a larger picture of Hanseatic activities at Notau, we should put emphasis on the following five points:

- The Hanseatic colony evacuated Bergen in 1427 and was re-established in 1433.

- There were Hanseatic merchants present in Notau between 1427 and 1433, or at least for part of the time. Piracy against Hanseatic ships occurred in Notau at least in 1430.

- Piracy is the reason the author of 'Die Nortsche Saw' gives as to why the Kontor left for a more secure location in Bergen.

- There was reorganization and strengthening of the Hanseatic settlement in Bergen in the years after the return in 1433.

- 'Bergen Fundas' states that it was during the reign of King Christopher that the colony of German merchants in Bergen was called a Kontor.

Notau might have been a more important harbour for Hanseatic merchants not belonging to the Wendish towns that left Bergen in 1427, and the Hanseatic presence here before the return to Bergen in 1433, during which time they were also attacked by pirates, could have been the starting point of a process that resulted in a better organized trading community in Bergen a few years after. After the return to Bergen, this might have given roots to a local narrative that the famous Kontor had once been situated at Notau, but that it had to be moved as a result of piracy.

We have no evidence which indicates that Notau was a location controlled by the Hanse. The provenance 
of the sources provides a clear bias, since it for the most part is of Hanseatic origin, and it is therefore of importance to avoid a reading which lets the origin of the sources set limitations to the interpretation. To get a better understanding of Notau, one should also have a clear focus on what written sources tell us about non-Hanseatic activity. What does seem to be the fact is that in the fifteenth century Notau was a soughtafter harbour for Hanseatic ships and that Hanseatic merchants traded there. However, there is nothing in the sources indicating that Notau was under Hanseatic control.

\section{Endnotes}

${ }^{1}$ Den norske So, in NM 2, 22.

${ }^{2}$ An overview is given by Fyllingsnes 2004.

${ }^{3}$ Bruns 1900, 56, 194, 242, 357, 384.

${ }^{4}$ Nesse 2010, 99.

${ }^{5}$ AM $8894^{\circ}$, AM $8954^{\circ}$, AM $8964^{\circ}$, AM $8974^{\circ}$, Kbh. Ubib. Add. 271, 4으, Kgl. Bib. Kallske saml. 591, $4^{\circ}$, Kgl. Bib. Gamle saml. 2836, $4^{\circ}$, Kgl. Bib. Nye saml. 1544 $4^{\circ}$, UiB Ms. $1574^{\circ}$, according to the editor N. Nicolaysen NM 2, 3, footnote 1. He also mentions a manuscript that he assumed was lost (AM 896, $4^{\circ}$ ). However, as far as my investigations can be relied on, I was able to see through this during a visit at AM (12 March 2007). On the other hand Nicolaysen mentions another manuscript, Kbh. Ubib. Add. 271, $4^{\circ}$, which, as far as I could see, did not contain Die Nortsche Saw, but read on the front page 'Kurtzer das Wahrhaften Bericht was zu Rendenburg zwischen Ihro Konigl. Maieß. zu dennemachen etc. und zu Schleswig, Holsten, etc. mit Regierenden Hoeh Fürstl. düchl. Respective deren beyhabenden Minstris vom 22 juni biß den 15. Julii dießes 1675 Jahreß pasiert. Anno 1675.' However, with one manuscript that Nicolaysen did not find, and one manuscript he mentioned, but which I cannot see is Die Nortsche Saw, we still end up with nine all together.

${ }^{6}$ Den norske So, in NM 2, 4.

${ }^{7}$ Den norske So, in NM 2, 4.

${ }^{8}$ Nesse 2010, 98f.

${ }^{9}$ Nesse 2007.

${ }^{10}$ Den norske So, in NM 2, 22. A version of Die Nortsche Saw in the manuscript collection at the UiB, Ms. $1574^{\circ}$, read as follows: 'Derwegen stifften sie / vier Vniversiteten oder handell stetter, in vier konichreichen / verlohren alß denn Nahmenn hense stetter, vnnd wurden / genömet handelsteter, fingen an mit kauffenschop zu handelen / zu waßer vnnd zu lande, die wier orter zu vnivisitiren [new page] geornet nentenn sie Conthor, daß erst legten sie gen Bruck / in flanderen, alda verweselen sie godt vnd silber, edle gesteinn/ Sammit vnd Seydenn, welcheß auß Spannien dahin gesehnet / wurdt Daß ander legtenn sie genn Lunden in Engelandt / daselbeß handelen sie meist mit laken, furthen widerum wahre / Vnnd geldt dahinn, daß driete conthor legtenn sie gen Nouw=/ gartenn in
Rußlandt, daßes da selbest gefiellen marten / zobelen wax talch vnnd andere teuer wahre, dahin furten sie / goldt, geldt, gemacht Sielber, Sammit, vnd seiden, vnnd / Engelsche lakenn, daß vierte vnnd letzte canthor legten sie / in Norwegenn, vahr einn zeitlangh zu Notauw, doch wegen / der See reuber muste es an einnen gelegen art alß genn / bergenn gelecht werdenn, da nu alle canthor fein vnd / woll geordenet werdenn auff ihre weise mit klugen / weißenn rath, vber all woll vorstehenn, wusten die guter / van einnen ort zu dem anderen zu sendenn vnd waß sie an ieder / conthor sendenn soltenn, vnnd hiriegen in nehmen, alß die laken / nach Rußlandt, hiriegenn als die teuersten wahren alß / Maretenn zobelenn nach Hispannien, beher, Brodt, mell / vnd malt nach Bergenn, Hiriegen die fisch vnd Trann / in die Kloister, Summa alle dinge wahren woll...' I would like to thank Agnete Nesse at Bergen University College for letting me use her transcription of the manuscript.

${ }^{11}$ Den norske So, in NM 2, $23 \mathrm{f}$.

${ }^{12}$ Den norske So, in NM 2, 24.

${ }^{13}$ Bergen Fundas, 7.

${ }^{14}$ As for The Nortsche Saw N. Nicolaysen also published Bergens Fundas, NM 1. However, the latter was given a new edition by philologist M. Sørlie in 1957.

${ }^{15}$ Bergen Fundas, 36, 47-49.

16 'Die Chronik Christians von Geren', in Die Lübecker Bergenfahrer und Ihre Chronistik, 349. In Bergen Fundas the author is reffering to a meeting held in Bergen by the Norwegian Sovereign Council, where the German merchants themselves are referring to their return after their agreement with King Erik ('...siiden wij er komne i Landit igienn,..' and '...siden wij [ere] Atter indkomne,.. '). Bergen Fundas, 50.

${ }^{17}$ HR II, 1, no. 139 (pp. 92-94). 'Die Chronik Christians von Geren', in Die Lübecker Bergenfahrer und Ihre Chronistik, 349.

${ }^{18}$ NGL I, 234-257; Helle 1982, 783.

${ }^{19}$ Helle 1982, 732.

${ }^{20}$ Dollinger 1981, 136; Hammel-Kiesow 2004, 63.

${ }^{21}$ Nielsen 1877, 204, 227, 231.

${ }^{22}$ Den Norske So, in NM 2, 24; Ersland 2014, 92.

${ }^{23}$ Bergen Fundas, 48f., 54f.; NGL I, 234-257.

24 '...vahr einn zeitlangh zu Notauw'.

${ }^{25}$ Ersland 2008, 13; Ersland 2014, 95.

${ }^{26}$ HR I, 8, no. 102, p. 73f. 'Die Chronik Christians von Geren', in Die Lübecker Bergenfahrer und Ihre Chronistik, 349.

${ }^{27}$ DN VII, no. 382 .

${ }^{28}$ Nielsen 1877, 227f. Nielsen suggests that this might have given the towns that withdrew from Bergen a motif for encouraging the Victual Brothers to attack and destroy the town.

${ }^{29} H R$ II, 1, no. $362 \$ \$ 39$ and 62, pp. 283f. ('by Notow') and 286 ('upp Notoy'); Fyllingsnes 2004, 5.

${ }^{30}$ HUB 6, no. 1071, pp. 597f.

${ }^{31}$ HUB 6, no. 1075, pp. 599f.; HR II, no. $385 \$ 11$, p. 300. The Victual Brothers also attacked and plundered Bergen in 1428 and 1429. We have no information of any ships from Danzig or any other Hanseatic town visiting Bergen in these years. 
${ }^{32}$ HR II, 1, no. $321 \S 6$, p. 203 and editor's comments on no. 381, p. 277.

${ }^{33}$ Fyllingsnes 2004, 13.

34 'Item to Berghen in Norweghene geve ik to den buweten der kerken darbynnen liggende 2 last teres, isliker darvan to gevende, daran ze behovet. Item to s. Katherinen unde s. Dorothen gilde darsulves geve ik $4 \mathrm{mr}$. Lub. Item to Notow geve ik 2 tunnen teres to dem buwe'. 'Die Testamente der Lübecker Bergenfahrer', no. 82, in Die Lübecker Bergenfahrer und Ihre Chronistik, 56.

${ }^{35}$ Ibid., 10-151.

${ }^{36}$ Henrik Kalteisens Kopibog, XXVI, 154, 163; Fyllingsnes 2004, $5 \mathrm{f}$.

${ }^{37}$ HR II, 4, no. $349 \$ 4$; DN XVI, no. 291; Fyllingsnes 2004, 6.

${ }^{38}$ HR II, 7, no. 343 p. 539 and no. 416 p. 659; Fyllingsnes 2004, 6f.

39 'Das Schüttingsrechnungsbuch 1471' in Die Lübecker Bergenfahrer und Ihre Chronistik, 242.

${ }^{40}$ Helle 1993, 157.

${ }^{41}$ Ersland and Solli 2012, 118-121.

${ }^{42}$ NGL I, no. 64.

${ }^{43}$ HR II, 1 , no. 69 , p. 47.

\section{References}

Unpublished documents (see also list of abbreviations)

UiB. Ms. = Universitetsbiblioteket i Bergen, Manuskriptsamlingen.

Printed sources (see also list of abbreviations)

Bergen Fundas, ed. by M. Sørlie. Bergen: Beyer, 1957.

Die Lübecker Bergenfahrer und Ihre Chronistik, by F. Bruns. Berlin: Pass und Garleb, 1900.
Henrik Kalteisens Kopibog, ed. by A. Bugge. Christiania: Aktieselskabet Thronsen \& Co.s Bogtrykkeri, 1899.

NM - Norske Magasin 1-3, ed. by N. Nicolaysen. Christiania: Johan Dahls Forlagshandel, 1858-1870.

\section{Secondary literature}

Dollinger, P. 1981. Die Hanse. Stuttgart: Alfred Kröner Verlag.

Ersland, G. A. 2008. The Archive of the Kontor in Bergen, in G. A. Ersland and M. Trebbi (eds), Neue Studien zum Archiv und zur Sprache der Hanseaten. Det Hanseatiske Museums skrifter 28, 8-24. Bergen: Museum Vest - Det Hanseatiske Museum.

Ersland, G. A. 2014. Das Handelsgericht des Hansekontors in Bergen, in M. Hundt and J. Lokers (eds), Hanse und Stadt. Festschrift für Rolf Hammel-Kiesow zum 65. Geburtstag, 89-102. Lübeck: Schmidt-Römhild.

Ersland, G. A. and Solli, A. 2012. Biskopby og borgarby. Stavanger: Wigestrand.

Fyllingsnes, F. 2004. Notow - hanseatane si hamn på Avaldsnes. Heimen 1, 3-21.

Hammel-Kiesow, R. 2004. Die Hanse. München: C. H. Beck (3rd edition).

Helle, K. 1975. Stavanger fra våg til by. Stavanger: Dreyer.

Helle, K. 1982. Bergen bys historie, vol. I: Kongesete og kjøpstad. Bergen: Universitetsforlaget.

Helle, K. 1993. Rikssamlingen etter Harald Hårfagre, in Rikssamlingen og Harald Hårfagre. Karmøyseminaret 1993, 147-61. Kopervik: Karmøy kommune.

Nesse, A. 2007. Bergens Tidende (Newspaper), 20.05.2007. Nesse, A. 2010. Norwegisch-niederdeutsche Sprachkontakte. Niederdeutsches Jahrbuch 133, 87-104.

Nielsen, Y. 1877. Bergen fra de celdste Tider og indtil Nutiden. Christiania: Chr. Tønsbergs Forlag. 